
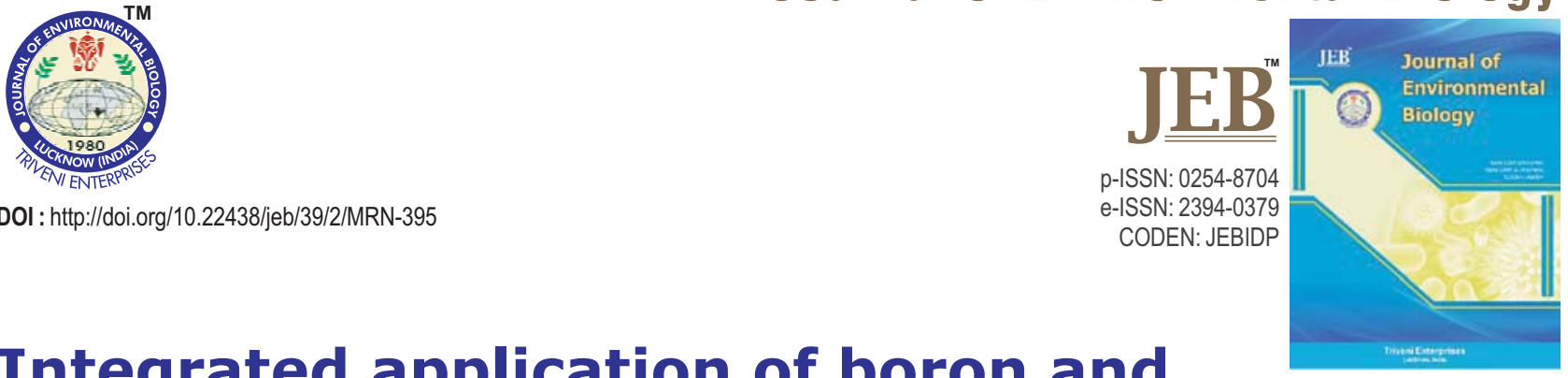

\title{
Integrated application of boron and sulphur to improve quality and economic yield in potato
}

\section{Authors Info}

S.K. Singh ${ }^{1 *}$, M. Sharma ${ }^{2}$, K.R. Reddy ${ }^{\prime}$ and T. Venkatesh ${ }^{1}$

'Department of Horticulture, Lovely Professional University, Phagwara -144 411, India

${ }^{2}$ Department of Vegetable Science, Punjab Agriculture University, Jalandhar-141 004, India

*Corresponding Author Email shailesh.19105@lpu.co.in

Key words

Boron

Intergrated application

Photosynthetic activity

Solanum tuberosum

Sulphur

Publication Info

Paper received : 30.07 .2016

Revised received: 06.04 .2017

Re-revised received: 18.05.2017

Accepted: 01.07.2017

\begin{abstract}
Aim : Plant nutrient management through application of sulphur in combination with boron is essential practice to sustain economic and quality yield in potato. The present investigation was performed to determine the economic performance of potato cultivation against integration of sulphur and boron with high grade fertilizers.
\end{abstract}

Methodology : The field was supplied with recommended dose of $\mathrm{N}, \mathrm{P}$ and $\mathrm{K}(120: 80: 100 \mathrm{~kg}$ $\mathrm{N}, \mathrm{P}_{2} \mathrm{O}_{5}$ and $\mathrm{K}_{2} \mathrm{O}$ per ha'). Sulphur (wettable sulphur) and boron (borovin) were applied as both, basal dose and foliar spray at 30 and 60 DAS (days after sowing). Intercultural practices were carried out as per recommendation and observations were recorded on chlorophyll content, yield and economic attributes. Duncan's New Multiple Range Test was applied for statistical analysis of observations.

Results : Foliar application of sulphur or boron was reported to have significant effect on dry matter and starch level in potato tubers, however highest dry matter $(26.31 \%)$ and starch $(71.37 \%)$ content was recorded in $\mathrm{T}_{9}$ (2 foliar sprays of $0.5 \%$ borovin and $0.25 \%$ sulphur). This was further reported with highest economic yield (360 q ha'), gross income (Rs. $2,88,000$ ), net income (Rs. 2, 14, 900) and B:C ratio (2.940:1), followed by $\mathrm{T}_{3} ; \mathrm{T}_{5} ; \mathrm{T}_{8}$ and $\mathrm{T}_{6}$.

Interpretation : Sulphur and boron application has been reported to bring significant influence on the chlorophyll level of potato plants consequently photosynthetic activity was also influenced. The improved photosynthetic activity had increased the fresh weight of potato tubers, dry matter and starch content of potato tubers when sulphur was applied as foliar application in combination with boron or alone. The tuber yield and $\mathrm{B}: \mathrm{C}$ ratio was also observed to be significantly increased due to foliar application of sulphur alone or in combination with boron.

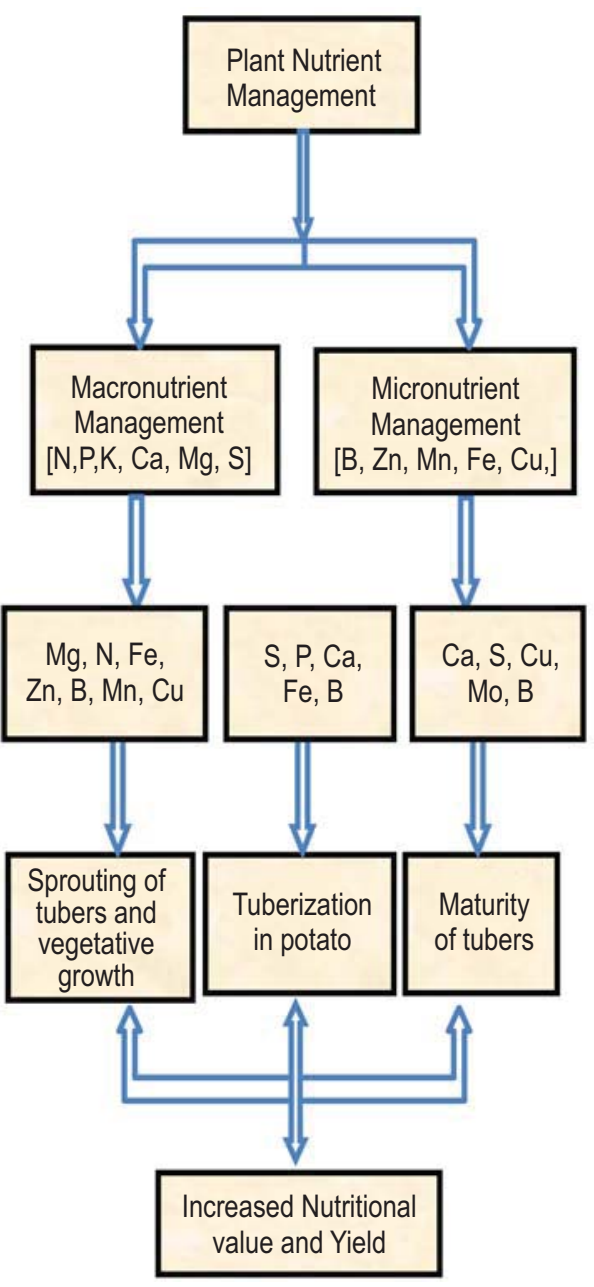




\section{Introduction}

Potato (Solanum tuberosum), a solanaceous crop, bears underground tuber as edible fraction which is a modified stem. Tubers are starchy and contain fair amount of vitamins, minerals, carotenoids and natural phenols. Potato is rich source of carbohydrate and predominant part of this carbohydrate is starch. Potato is an intensive crop and requires nutrients at high rate due to higher dry matter production in given area and time as compared to other field crops. Since most of the soils are poor in available nutrients and the crop has shallow and sparse root system, nutrient demand is generally not met by soil.

Proper dose of nitrogen has significant impact on the quality and yield of the potatoes through increased leaf area, photo assimilation and tuber growth (Vaezzadeh and Naderidarbaghshahi, 2012). Phosphorus is required during early phase of growth to enhance rooting and tuber formation, while in later phase it promotes bulk. Potassium is essential for transportation of nutrients, photosynthetic products and assimilatory products from source to sink. Intensive cropping and application of high-grade nitrogenous, phosphatic and potassic fertilizers to achieve optimum productivity in potato can increase the cost of cultivation and may lead to deficiency of secondary macronutrients and micronutrients (Modgal et al., 1995). Application of micronutrients can improve economic yield of potato through alteration of major nutrients uptake and utilization. Thus, nitrogen and potassium level in plants might be function of micronutrient application (Almodares et al., 2008).

Sulphur is secondary macronutrient and fourth most required element after nitrogen, phosphorus and potassium to sustain the plant growth and yield because of its need in many biochemical reactions (Sud and Sharma, 2002). Improved soil fertility, grain yield and crude protein in grams due to application of sulphur in combination with phosphorous fertilizers has also been reported by Deshbhratar et al. (2010). Plants with sulphur deficiency show poor nitrogen, phosphorus and potash assimilation and reduced catalase activity (Nasreen et al., 2008). Sulphur deficiency leads to cysteine and leucine deficiency, and hence to poor dry matter production (Eppendorfer and Eggum, 1994). Sulphur application has been reported to improve the availability of micronutrients like iron, zinc, manganese and copper to the plant by lowering soil pH (El-Tantawy and El-Beik, 2009). Regular removal of sulphur from soil have affected Sbudget of soil throughout the world (Aulakh et al., 1977) so recently there is an increase in awareness about the role of sulphur application on soil (Bloem et al., 2004).

Boron is second most widespread and economically important micronutrient which is essential for several growth related parameters. Its requirement is high after 45 days of crop emergence and remain high till crop maturity. It improves calcium absorption and stabilizes calcium in cell wall. Boron reduces the oxidation of phenols and prevent discolouration of tubers. Boron deficiency induces the internal breakdown of tubers in sugarbeet, turnip and potatoes (Brown et al., 2002). Approximately, $90 \%$ of boron in plants is accumulated in cell walls so it is associated with cell wall formation, functioning and strength (Blevins and Lukaszewski, 1998). Thus, boron deficiency results in extensive branching and poor growth due to loss of apical dominance (Cakmak and Römheld, 1997). Rashid et al. (2002) reported the severity of boron deficiency with the advancement of time and confirmed its necessity for plant fertilization. Hopkins et al. (2007) had studied the role of boron on tuberization and yield in potato and reported a non-significant increase due to soil or foliar application of boron. Boron does not 't have direct influence on yield or related attributes, however it plays supplementary role when applied with sulpur (Bari et al., 2001).

Considering the significance of sulphur and boron fertilizers for growth and yield of potato, the present study was conducted to assess the optimum combination and method of boron and sulphur application for economic yield and potato quality.

\section{Materials and Methods}

Study area : The present study was carried out at Lovely Professional University, Jalandhar, Punjab during the year 20152016.

Land preparation and sowing of tubers : The land was ploughed with the help of tractor by using cultivar and rotavator to get the fine tilth. The land was levelled and the field was laid out in experimental plots $(3 \mathrm{~m} \times 2 \mathrm{~m})$ as per plan. Seed tubers $(30-40 \mathrm{~g})$ were removed from cold store 10 days prior to planting and were spread in shade for proper sprouting. The complete dose of phosphorus $\left(80 \mathrm{~kg} \mathrm{ha}^{-1}\right)$ and potassium $\left(100 \mathrm{~kg} \mathrm{ha}^{-1}\right)$ along with half of recommended dose of nitrogen $\left(120 \mathrm{~kg} \mathrm{ha}^{-1}\right)$ was applied at the time of planting. The remaining half dose of nitrogen was applied at the time of earthing. The sprouted seed tubers were planted during $2^{\text {nd }}$ week of October 2015 by dibbling on ridges at the spacing of $60 \times 20 \mathrm{~cm}$. Tubers were covered with soil after planting with the help of a spade.

Intercultural practices : Experimental plots were kept free from weeds throughout the crop growth. Earthing up was done along with application of remaining dose of nitrogenous fertilizerat 45 DAS when potato plants were $12-18 \mathrm{~cm}$ high. Soil and foliar application of elemental sulphur and boroven as a source of boron was carried out as per treatments (Table 1). Two irrigations, one before seed bed preparation and other after a week, were applied before crop emergence while subsequent irrigation were applied as per requirement. Plant protection measures were adopted as per incidence of insects, pests and disease. Potatoes were dug manually at the end of January 2016.

Chlorophyll content : Total chlorophyll content of leaves was determined at 60 days after emergence. Leaves were rinsed in $85 \%$ acetone solution and absorbance was read at $663 \mathrm{~nm}$ and $645 \mathrm{~nm}$ wavelength. Chlorophyll content was calcutated (Arnon, 1949) and expressed in $\mathrm{mg} \mathrm{g}^{-1} \mathrm{f}$. wt. 
Table 1 : Treatment schedule of boron and sulphur during experimental period on potato in October 2015 - January 2016

\begin{tabular}{|c|c|c|}
\hline \multicolumn{2}{|c|}{ Treatments } & \multirow{2}{*}{$\begin{array}{l}\text { Application time and methodology } \\
\text { Applied as basal dose during sowing }\end{array}$} \\
\hline $\mathrm{T}_{1}$ & Borovin $\left(1 \mathrm{~g} \mathrm{~m}^{-2}\right)$ & \\
\hline $\mathrm{T}_{2}$ & Borovin $\left(0.5 \mathrm{~g} \mathrm{~m}^{-2}\right)+$ One foliar spray ( $0.5 \%$ borovin) & $\begin{array}{l}\text { Applied as basal dose during sowing and again as foliar spray after } 30 \\
\text { days of sowing }\end{array}$ \\
\hline $\mathrm{T}_{3}$ & Two foliar sprays ( $0.5 \%$ borovin) & Applied as foliar spray after 30 days and again 60 days of sowing \\
\hline $\mathrm{T}_{4}$ & Sulphur $\left(0.5 \mathrm{~g} \mathrm{~m}^{-2}\right)$ & Applied as basal dose during sowing \\
\hline $\mathrm{T}_{5}$ & Sulphur $\left(0.25 \mathrm{~g} \mathrm{~m}^{-2}\right)+$ One foliar spray $(0.25 \%$ sulphur $)$ & $\begin{array}{l}\text { Applied as basal dose during sowing and again as foliar spray after } 30 \\
\text { days of sowing }\end{array}$ \\
\hline $\mathrm{T}_{6}$ & Two foliar sprays ( $0.25 \%$ sulphur) & Applied as foliar spray after 30 days and again 60 days of sowing \\
\hline $\mathrm{T}_{7}$ & Borovin $\left(0.5 \mathrm{~g} \mathrm{~m}^{-2}\right)+$ sulphur $\left(0.25 \mathrm{~g} \mathrm{~m}^{-2}\right)$ & Applied as basal dose during sowing \\
\hline $\mathrm{T}_{8}$ & $\begin{array}{l}\text { Borovin }\left(0.5 \mathrm{~g} \mathrm{~m}^{-2}\right)+\text { sulphur }\left(0.25 \mathrm{~g} \mathrm{~m}^{-2}\right)+\text { Two foliar } \\
\text { spray }(0.5 \% \text { borovin and } 0.25 \% \text { sulphur })\end{array}$ & $\begin{array}{l}\text { Applied as basal dose during sowing and again as foliar spray after } 30 \\
\text { days of sowing }\end{array}$ \\
\hline $\mathrm{T}_{9}$ & Two foliar sprays ( $0.5 \%$ borovin and $0.25 \%$ sulphur) & Applied as foliar spray after 30 days and again 60 days of sowing \\
\hline$T_{10}$ & Control & Boron and sulphur was not applied \\
\hline
\end{tabular}

Table 2 : Yield related attributes of potato after different treatment schedule of boron and sulphur

\begin{tabular}{lllll}
\hline Treatments & $\begin{array}{l}\text { Fresh weight } \\
\text { of potato tuber } \\
\text { (in g plant } \text { ( }^{-1}\end{array}$ & $\begin{array}{l}\text { Volume } \\
\text { (cc) }\end{array}$ & $\begin{array}{l}\text { Specific } \\
\text { gravity } \\
\left(\text { ( c cc }^{-1} \text { ) }\right.\end{array}$ & $\begin{array}{l}\text { Average yield } \\
\text { (kg plot }^{-1} \text { ) }\end{array}$ \\
\hline $\mathrm{T}_{1}$ & $515.00^{\mathrm{bc}}$ & $505.00^{\mathrm{b}}$ & $1.020^{\mathrm{b}}$ & $11.80^{\mathrm{b}}$ \\
$\mathrm{T}_{2}$ & $595.00^{\mathrm{bc}}$ & $580.00^{\mathrm{ab}}$ & $1.025^{\mathrm{b}}$ & $14.00^{\mathrm{ab}}$ \\
$\mathrm{T}_{3}$ & $795.00^{\mathrm{a}}$ & $741.67^{\mathrm{a}}$ & $1.077^{\mathrm{b}}$ & $21.50^{\mathrm{a}}$ \\
$\mathrm{T}_{4}$ & $641.00^{\mathrm{b}}$ & $490.00^{\mathrm{b}}$ & $1.320^{\mathrm{a}}$ & $15.00^{\mathrm{ab}}$ \\
$\mathrm{T}_{5}$ & $765.00^{\mathrm{ab}}$ & $735.00^{\mathrm{a}}$ & $1.041^{\mathrm{b}}$ & $20.50^{\mathrm{a}}$ \\
$\mathrm{T}_{6}$ & $740.00^{\mathrm{ab}}$ & $695.00^{\mathrm{a}}$ & $1.077^{\mathrm{b}}$ & $19.80^{\mathrm{a}}$ \\
$\mathrm{T}^{7}$ & $472.50^{\mathrm{c}}$ & $455.00^{\mathrm{b}}$ & $1.037^{\mathrm{b}}$ & $10.60^{\mathrm{b}}$ \\
$\mathrm{T}^{8}$ & $670.00^{\mathrm{ab}}$ & $665.00^{\mathrm{ab}}$ & $1.007^{\mathrm{b}}$ & $20.40^{\mathrm{a}}$ \\
$\mathrm{T}_{9}$ & $786.67^{\mathrm{ab}}$ & $715.00^{\mathrm{a}}$ & $1.106^{\mathrm{b}}$ & $21.60^{\mathrm{a}}$ \\
$\mathrm{T}_{10}$ & $470.00^{\mathrm{c}}$ & $453.50^{\mathrm{b}}$ & $1.036^{\mathrm{b}}$ & $9.20^{\mathrm{b}}$ \\
$\mathrm{GM}$ & 645.02 & 603.52 & 1.075 & 16.44 \\
$\mathrm{SEm}( \pm)$ & 51.509 & 58.309 & 0.042 & 2.13 \\
$\mathrm{CD}$ & 153.05 & 173.25 & 0.124 & 7.65 \\
$\mathrm{CV}$ & 13.832 & 16.734 & 6.712 & 0.69 \\
\hline
\end{tabular}

Yield related attributes : Tubers from each randomly selected plant were taken to determine fresh weight, volume and specific gravity. The fresh weight ( $\mathrm{g} \mathrm{plant}^{-1}$ ) of tubers was taken by using electric balance while volume was taken by using measuring cylinder and average was calculated. Specific gravity was calculated and expressed as $\mathrm{g} \mathrm{cc}^{-1}$. Average yield per plot was determined by taking weight of potato tubers harvested from each plot and was further converted to per hectare yield.

Chemical composition of potato tuber : The harvested tubers were chopped as cubes and dried in sun then oven at $65^{\circ} \mathrm{C}$ for 72 hrs to achieve constant weight. The dry matter content was determined by means of drier method and starch content were determined by spectrophotometric method described by Chopra and Kanwar (1976).
Economic analysis : The cost of cultivation was determined by using all inputs as per treatments and the market price while gross monetary returns in rupees per hectare was calculated on the basis of potato yield and prevailing market price of potato. The net income and benefit-cost ( $\mathrm{B}: \mathrm{C})$ ratio was calculated.

Statistical analysis : The significance of various treatments under study was analyzed through New Multiple Range Testing proposed by Duncan (Gomez and Gomez, 1984).

\section{Results and Discussion}

The observation recorded on chlorophyll content (Fig. 1) of potato leaves justified significant effect of foliar application of sulphur and boron. All treatments were reported with high level of chlorophyll in fresh weight of leaves in comparison to control $\left(T_{10}\right)$ except $T_{4}$, however highest chlorophyll was reported in $T_{3}$ $\left(11.57095 \mathrm{mg} \mathrm{g}^{-1}\right)$ followed by $T_{9}\left(8.20048 \mathrm{mg} \mathrm{g}^{-1}\right), T_{8}(6.64002$ $\left.\mathrm{mg} \mathrm{g}^{-1}\right)$ and $\mathrm{T}_{6}\left(6.36794 \mathrm{mg} \mathrm{g}^{-1}\right)$. High level of chlorophyll in plants supplied with sulphur or/and boron might be associated with their ability to lower the toxic effect of heavy metals present in soil. Yadav et al. (2008) had confirmed that application of boron reduces chlorophyll degradation in radish leaves by lowering nikle toxicity. The increased value of chlorophyll in potato leaves due to application of sulphur has also been reported by Padhi et al. (2013). However, lower value of chlorophyll content in $T_{4}$ in the present investigation does not support its high value as a function of boron or sulphur. This variation may be due to variation in absorption of nitrogen and potassium containing fertilizers. AlMoshileh et al. (2005) observed a positive influence of potassium sulphate application on chlorophyll concentration.

All the treatments (Table 2) resulted in higher fresh weight of tubers in comparison to control. The highest fresh weight $(795.00 \mathrm{~g})$ of potato tubers per plant was reported in $T_{3}$ which was significantly higher than $T_{1}, T_{2}, T_{4}, T_{7}$ and $T_{10}$ and was closely followed by $T_{9}(786.67 \mathrm{~g}), T_{5}(765.00 \mathrm{~g})$ and $T_{6}(740.00 \mathrm{~g})$. 


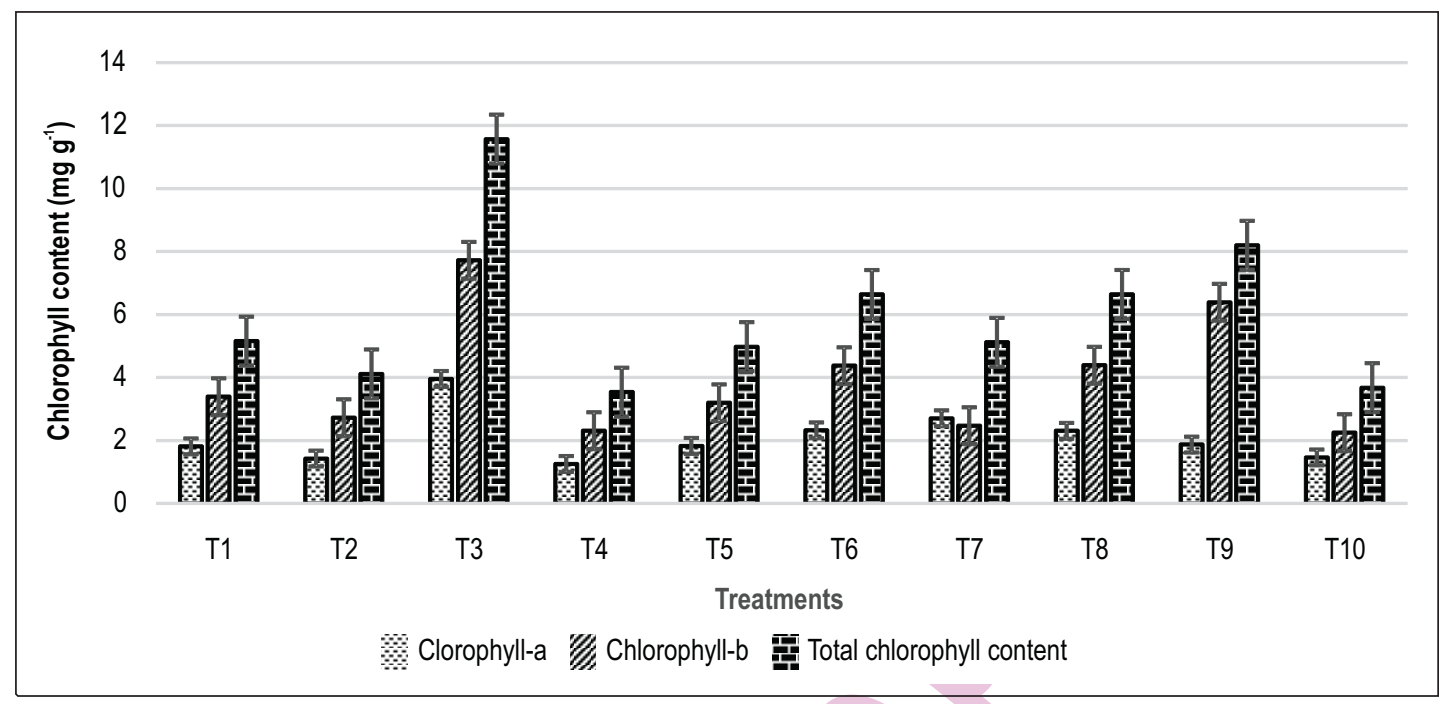

Fig. 1 : Variation in chlorophyll concentration of potato leaves measuredafter 60 days of tuber plantingunder different treatment schedule of boron and sulphur. Values are mean of three replicates \pm SD

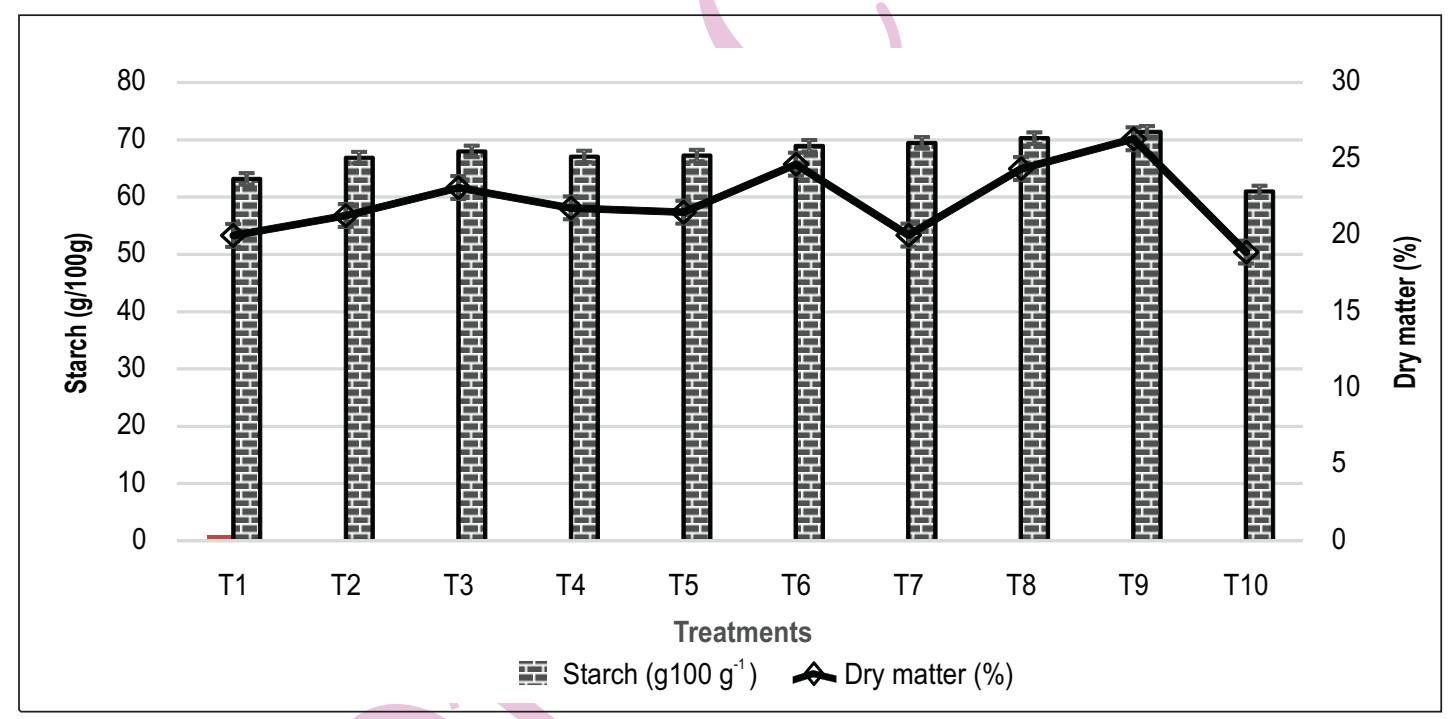

Fig. 2 : Variation in starch and dry matter content of potato tubersunder different treatment schedule of boron and sulphur. Values are mean of three replicates \pm SD

Similarly, highest volume $(741.67 \mathrm{cc})$ of potato tubers of a plant was reported in $\mathrm{T}_{3}$ followed by $\mathrm{T}_{5}(735.00 \mathrm{cc}), \mathrm{T}_{9}(715.00 \mathrm{cc})$ and $\mathrm{T}_{6}(695.00 \mathrm{cc})$. The specific gravity was reported to be highest in $\mathrm{T}_{4}\left(1.320 \mathrm{~g}^{-1} \mathrm{cc}\right)$ which was significantly higher than all other treatments. The significantly high per plot marketable yield was reported in $T_{9}(21.60 \mathrm{~kg})$ followed by $T_{3}(21.50 \mathrm{~kg}), T_{5}(20.50 \mathrm{~kg})$, $\mathrm{T}_{8}(20.40 \mathrm{~kg})$ and $\mathrm{T}_{6}(19.80 \mathrm{~kg})$ while the lowest was reported in $\mathrm{T}_{10}(9.20 \mathrm{~kg})$. The high value of fresh weight per plant, volume of tuber, specific gravity and marketable yield per plot in these treatment was due to higher rate absorption or uptake of major nutrients like N, P and K by the plants (Sud et al., 1990; Sud,
2006) which in turn improved plant metabolism and photosynthetic rate as well. This clearly reflects the positive influence of boron and/or sulphur application on the yield related attributes. The present proposal is being confirmed with the findings of Sud and Sharma (2002) who had reported potato tuber yield as function of sulphur level applied. Lalitha et al.(2002) had also confirmed about increased tuber yield and bulking due to application of sulphur in potato. Dabhi et al. (2004) and Sankaran et al. (2005) have also reported increased uptake of nutrients in presence of sulphur and yield in onion. Improvement in potasium and calcium uptake due to foliar application of boron had also been reported by Reinbott and 
Table 3 : Economic yield and Benefit- Cost analysis of potato cultivation after different treatment schedule of boron and sulphur

\begin{tabular}{llllll}
\hline Treatments & $\begin{array}{l}\text { Average economic } \\
\text { yield }\left(\mathbf{q} \text { ha }^{-1}\right)\end{array}$ & $\begin{array}{l}\text { Cost of cultivation } \\
\text { (Rs.) }\end{array}$ & $\begin{array}{l}\text { Gross income } \\
\text { (Rs.) }\end{array}$ & $\begin{array}{l}\text { Net income } \\
\text { (Rs.) }\end{array}$ & $\begin{array}{l}\text { Benefit: Cost } \\
\text { Ratio }\end{array}$ \\
\hline$T_{1}$ & 196.67 & 73,500 & 157,336 & 83,836 & $1.141: 1$ \\
$T_{2}$ & 233.33 & 73,250 & 186,664 & 113,414 & $1.548: 1$ \\
$T_{3}$ & 358.33 & 73,000 & 286,664 & 213,664 & $2.927: 1$ \\
$T_{4}$ & 250.00 & 72,700 & 200,000 & 127,300 & $1.751: 1$ \\
$T_{5}$ & 341.67 & 72,650 & 273,336 & 200,686 & $2.768: 1$ \\
$T_{6}$ & 330.00 & 72,600 & 264,000 & 191,400 & $2.636: 1$ \\
$T_{7}$ & 176.67 & 73,100 & 141,336 & 68,236 & $0.933: 1$ \\
$T_{8}$ & 340.00 & 73,400 & 272,000 & 198,600 & $2.706: 1$ \\
$T_{9}$ & 360.00 & 73,100 & 288,000 & 214,900 & $2.940: 1$ \\
$T_{10}$ & 153.33 & 72,500 & 122,664 & 50,164 & $0.692: 1$ \\
$T_{M}$ & 274.00 & 72,980 & 219,200 & 146,220 & $2.004: 1$ \\
\hline
\end{tabular}

Blevins (1995) in tomato. Stunted growth and poor yield in boron deficient tomato plants have also been reported by Davis et al. (2003), which might be associated with reduced nitrogen uptake by the plant. These results can be further confirmed by the findings of Zaman et al. (2011); Klikocka (2011); Pavlista (2010); Farooqui et al. (2009) and Zengin et al. (2009), respectively.

The result pertaining to dry matter and starch content of potato tubers, presented in Fig. 2 revealed highest dry matter

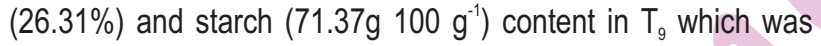
significantly better than all other treatments. $T_{9}$ was followed by $T_{6}$ $(24.65 \%)$ and $\mathrm{T}_{8}(24.36 \%)$ in dry matter content while $\mathrm{T}_{8}(70.27 \mathrm{~g}$ $\left.100 \mathrm{~g}^{-1}\right)$ and $\mathrm{T}_{7}\left(69.45 \mathrm{~g} 100 \mathrm{~g} \mathrm{~g}^{-1}\right)$ in starch content. The lowest level of dry matter $(18.90 \%)$ and starch $\left(60.97 \mathrm{~g}^{\left.100 \mathrm{~g}^{-1}\right)}\right.$ content of potato tuber was reported with control $\left(\mathrm{T}_{10}\right)$ when plants were not supplied with sulphur and boron. The high level of dry matter and starch content in tubers of plant treated with sulphur alone or in combination of boron was due to increased absorption of available soil nutrient and high rate of photosynthesis. This result can be confirmed by the findings of Sharma et al. (2011) who had proved significantly high yield and quality of potato tubers in terms of DM, specific gravity, starch content and sugar level due to application of sulphur. Yadav et al. (2008) had also reported improvement in sugar mobilization, DNA and protein synthesis in radish with increasing concentration of boron by reducing $\mathrm{Ni}$ toxicity. Similar results have been published by Singh et al. (1995) and Shahen et al.(2013). Bhagvantagoudra and Rokhade (2002) noticed that application of $40 \mathrm{~kg}$ sulphur per ha gave highest yield and higher dry matter in cabbage. The plants without application of sulphur and boron $\left(\mathrm{T}_{10}\right)$ might be suffered with deficiency so dry matter and starch content was lowest $\left(18.90 \%\right.$ and $60.97 \mathrm{~g}^{100 \mathrm{~g}^{-1} \text {, }}$ respectively) and can be confirmed by the findings of Eppendorfer and Eggum (1994) and Petitte and Ormrod (1988) in potato due to sulphur deficiency and by Davis et al. (2003) in tomato due to boron deficiency.
The economic analysis (Table 3) confirms highest per hectare economic yield (360 quintals), gross income (Rs. 2, 88, 000), net income (Rs. 2, 14, 900) and B: C ratio $(2.940: 1)$ in $T_{9}$ which is closely followed by $T_{3}$ (358.33 quintals, Rs. 286 664, Rs 2, 13, 664 and $2.927: 1$, respectively), $T_{5}$ (341.67quintals, Rs. 2 73 336, Rs. 200686 and 2.768:1, respectively), T8 (340.00 quintals, Rs. 2, 72, 000, Rs. 1, 98, 600 and 2.706:1, respectively) and $\mathrm{T}_{6}$ ( 330.00 quintals, Rs. 2, 64, 00, Rs. 1, 91, 400 and 2.636: 1 , respectively). Soil or foliar application of boron and sulphur in potato provided higher economic yield, net income and benefit-cost ratio which might be associated with higher chlorophyll content and photosynthetic area to improve photosynthetic activity, plant metabolism and dry matter production. Sulphur induced high yield and benefit: cost ratio has been reported by Mitra et al. (2006) in summer green gram and by Nepalia (2005) in mustard while boron mediated improvement in yield, quality and economic return has been reported by Singh et al. (2005) due to application of $0.25 \%$ or $0.50 \%$ borax in Ranchi cultivar of papaya. These can be further confirmed by the findings of Raghav et al. (2007) and Singh et al. (2016).

The present findings thus suggests that application of boron or sulphur alone or in combination had significantly improved per plant yield of potato tuber, dry matter content, starch content, economic yield and net income to more than double.Thus, application of sulphur and boron in different phase of plant growth can be used to improve quality and economic yield in potato.

\section{Acknowledgment}

The authors would like to give their sincere thanks to Lovely Professional University-Punjab, India for the professional and financial support.

\section{References}

Almodares, A., R. Taheri, M. Chung and M. Fathi: The effect of nitrogen and potassium fertilizers on growth parameters and carbohydrate contents of sweet sorghum cultivars.J. Environ. Biol., 29, 849-852 
(2008).

Al-Moshileh, A.M., M.A. Errebhi and M.I. Motawei: Effect of various potassium and nitrogen rates and splitting methods on potato under sandy soil and arid environmental conditions. Emir. J. Agric. Sci., 17, 01-09 (2005).

Arnon, D.I.: Copper enzymes in isolated chloroplasts. Polyphenoloxidase in Beta vulgaris. Plant Physiol., 24 , 1-15 (1949).

Aulakh, M.S., B. Singh and B.R. Arora : Effect of sulphur fertilization on the yield and quality of potatoes (Solanum tuberosum L.). J. Indian Soc. Soil Sci., 25, 182-185 (1977).

Bari, M.S., M.G. Rabbani, M.S. Rahman, M.J. Islam and A.T.M.R. Hoque: Effect of zinc, boron, sulphur and magnesium on the growth and yield of potato. Pak. J. Biol. Sci., 4, 1090-1093 (2001).

Bhagvantagoudra, K.H. and A.K. Rokhade: Effect of sulphur nutrition on yield, quality and its uptake in cabbage. Karnataka J. Agric. Sci., 15, 182-185(2002).

Blevins, D.G. and K.M. Lukaszewski : Boron in plant structure and function. Annual Rev. a Plant Biol., 49, 481-500 (1998).

Bloem, E., H. Silvia and S. Ewald. Influence of nitrogen and sulfur fertilization on the allin content of onions and garlic. J. Plant Nutr., 27, 1827-1839 (2004).

Brown, P.H., N. Bellaloui, M.A. Wimmer, E.S. Bassil, J. Ruiz, H. Hu and V. Römheld : Boron in plant biology. Plant Biol., 4, 205-223 (2002).

Cakmak, I. and V. Römheld : Boron deficiency-induced impairments of cellular functions in plants. Plant Soil, 193, 71-83 (1997).

Chopra, S.L. and J.S. Kanwar : Analytical agricultural chemistry. Kalyani Publishers, Ludhiana, p. 365 (1976).

Dabhi, N.M., M.V. Patel and V.R. Patel : Effect of sources and levels of sulphur on yield and chemical composition of onion in loamy sand. National Seminar on Development in Soil Science: 69th Annual Convention, Hyderabad, India, p. 124 (2004).

Davis, J.M., D.C. Sanders, P.V. Nelson, L. Lengnick and W.J. Sperry: Boron improves growth, yield, quality, and nutrient content of tomato. J. Am. Soc. Hortic. Sci., 128, 441-446 (2003).

Deshbhratar, P.B., P.K. Singh, A.P. Jambhulkar and D.S. Ramteke: Effect of sulphur and phosphorus on yield, quality and nutrient status of pigeonpea (Cajanus cajan). J. Environ. Biol., 31, 933-937 (2010).

El-Tantawy, E.M. and A.K. El-Beik : Relationship between growth, yield and storability of onion (Allium cepa L.) with fertilization of nitrogen, sulphur and copper under calcareous soil conditions. Res. J. Agric. Biol. Sci., 5, 361-371 (2009).

Eppendorfer, W.H. and B.O. Eggum: Effects of sulphur, nitrogen, phosphorus, potassium, and water stress on dietary fibre fractions, starch, amino acids and on the biological value of potato protein. Plant Foods Hum. Nutr.,45, 299-313 (1994).

Farooqui, M.A., I.S. Naruka, S.S. Rathore, P.P. Singh and R.P.S. Shaktawat: Effect of nitrogen and sulphur levels on growth and yield of garlic. Asian J. Food Agro-Indus., Special Issues, S18-S23 (2009).

Gomez, K.A. and A.A. Gomez: Statistical procedure for agricultural research. $2^{\text {nd }}$ Edn., John Wiley and Sons, New York (1984).

Hopkins, B.G., V.D. Jolley, B.L. Webb, J. Ellsworth and R. Callahan: Boron fertilization in Potato. In : Western Nutrient Management Conference. Vol. 7, p. 215-218 (2007).

Klikocka, H.: The effect of sulphur kind and dose on content and uptake of micro-nutrients by potato tubers (Solanum tubersosum L.). Acta Sci. Pol., Hortorum Cultus., 2, 137-151 (2011).

Lalitha, B.S., K.H. Nagaraj and T.N. Anand: Effect of source propagation, level of potassium and sulphur on potato (Solanum tuberosum $\mathrm{L}$.). Mys. J. Agric. Sci., 36, 148-153 (2002).

Mitra, A.K., K. Banerjee and A.K. Pal: Effect of different levels of phosphorus and sulphur on yield attributes, seed yield, protein content of seed and economics of summer greengram. Res. Crops, 7, 404 (2006).

Modgal, S.C., Y. Singh and P.C. Gupta:Nutrient management in ricewheat cropping system. Fertiliser News, 40, 49-49 (1995).

Nasreen, S., M.M. Haque, M.A. Husain and A.T.M. Farid: Nutrient uptake and yield of onion as influenced by nitrogen and sulphur fertilization. Bangladesh J. Agric. Res., 32, 413-420 (2008).

Nepalia, V.: Influence of weed control and sulphur on growth, yield and economics of mustard production. Research on Crops, 6, 35 (2005).

Padhi, S.K., M. Dash and S.C. Swain : Effect of sulphur dioxide on growth, chlorophyll and sulphur contents of tomato. European Sci. J., 9, 465-471 (2013).

Pavlista, A.D.: Early-season applications of sulfur fertilizers to increase potato yield and reduce tuber defects. Agronomy J., 97, 599-603 (2005).

Petitte, J.M. and D.P. Ormrod: Effects of sulphur dioxide and nitrogen dioxide on shoot and root growth of Kennebec and Russet Burbank potato plants. Am. J. Potato Res., 65, 517-527 (1988).

Raghav, M., T. Kumar and S. Kamal : Effect oforganic sources of nutrients on growth,yield and quality of potato. Progress. Hort., 39, 95-100 (2007).

Rashid, A., E. Rafique and J. Ryan: Establishment and management of boron deficiency in field crops in Pakistan: country Report. In : Boron in Plant and Animal Nutrition (Ed.: H.E. Goldbach). Springer Science \& Business Media, U.S. pp.339-348 (2002).

Rashid, A., M.M. Mahmood, E. Rafique and K. Farooq: Potato responses to boron and zinc application in a calcareous Udic Ustochrept. In: Advances in Plant and Animal Boron Nutrition: Proceedings of $3^{\text {rd }}$ International Symposium on all Aspects of Plant and Animal Boron Nutrition, Springer Science \& Business Media, U.S.,p. 137 (2007).

Reinbott, T.M.and D.G. Blevins: Response of soybean to foliar-applied boron and magnesium and soil-applied boron.J.Plant Nutr.,18, 179-200 (1995).

Sankaran, K.,C. Bharathi and S. Sujatha: Effect of sulphur fertilization on yield and nutrient uptake by onion in red soil (Uodic Haplustalf). J. MaharastraAgril. Univ., 30, 135-136 (2005).

Shahen, A.M., A.R. Fatma, G.B. Awatef and Y.I. Helmy: The role of sulphur and bio-phosphorus in potato plant growth and its productivity in newly soil. Res. J. Agric. Biol. Sci., 9, 119-126 (2013).

Sharma, D.K., S.S. Kushwah, P.K. Nema and S.S. Rathore: Effect of sulphur on yield and quality of potato. Int. J. Agric. Res., 6, 143-148 (2011).

Singh, D.K., P.K. Paul and S.K. Ghosh: Response of papaya to foliar application of boron, zinc and their combinations. Res. Crops, $\mathbf{6}$, 277 (2005).

Singh, H., M. Sharma, A. Goyal and M. Bansal: Effect of nitrogen and sulphur on growth and yield attributes of potato (Solanum tuberosum L.). Int. J. Plant Soil Sci., 9, 1-8 (2016).

Singh, J.P., R.S. Marwaha and O.P. Srivastava: Processing and nutritive qualities of potato tubers as affected by fertilizer nutrients and sulphur application. J. Indian Potato Assoc., 22, $32-37$ (1995).

Sud, K.C. and R.C. Sharma: Sulphur needs of potato under rainfed conditions in Shimla Hills. In: Potato Global Research and Development (Eds.: S.M.P. Khurana, G.S. Shekhawat, S.K. Pandey and B.S. Singh). Shimla, Vol. 2, p. 889-899 (2002).

Sud, K.C., J.S. Grewal and S.P. Trehan : Effect of farmyard manure and N on potato (Solanum tuberosum) production and phosphorus and potassium availability in hill soils of Shimla. Ind. J. Agric. Sci., 60, 529-532(1990).

Sud, K.C. : Anionic balance of nitrogen, phosphorus and sulphur in potato leaves under rainfed conditions in Shimla hills. Potato J., 
$33,68-73(2006)$.

Vaezzadeh, M. and M. Naderidarbaghshahi: The effect of various nitrogen fertilizer amounts on yield and nitrate accumulation in tubers of two potato cultivars in cold regions of Isfahan (Iran). Int. J. Agri. Crop Sci., 4, 1688-1691 (2012).

Yadav, S.S., R. Shukla and Y.K. Sharma: Nickel toxicity on seed germination and growth in radish (Raphanus sativus) and its recovery using copper and boron. J. Environ. Biol., 30, 461-466
(2009).

Zaman, M.S, M.A. Hashem, M Jahiruddin and M.A. Rahim: Effect of sulphur fertilization on the growth and yield of garlic (Allium sativum L.). Bangladesh J.Agric. Res., 36, 647-656 (2011).

Zengin, M., F. Gökmen, M.A. Yazici and S. Gezgin : Effects of potassium, magnesium, and sulphur containing fertilizers on yield and quality of sugar beets (Beta vulgaris L.). Turk. J.Agric. For., 33, 495-502 (2009).

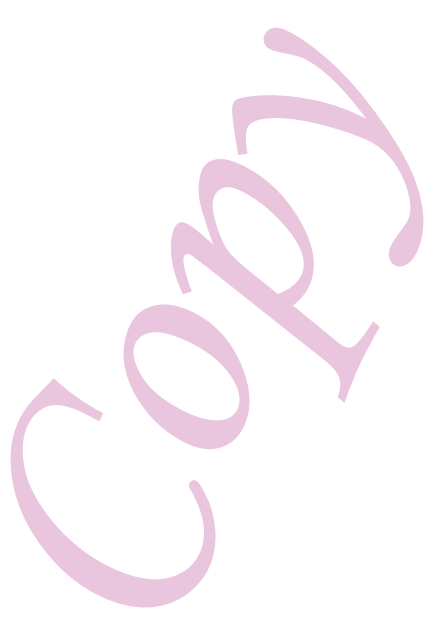

